\title{
Article \\ Suffering in the Race for Happiness
}

Bina Nir

check for updates

Citation: Nir, Bina. 2021. Suffering in the Race for Happiness. Genealogy 5: 61. https://doi.org/10.3390/ genealogy5030061

Received: 7 June 2021

Accepted: 23 June 2021

Published: 26 June 2021

Publisher's Note: MDPI stays neutral with regard to jurisdictional claims in published maps and institutional affiliations.

Copyright: (C) 2021 by the author. Licensee MDPI, Basel, Switzerland. This article is an open access article distributed under the terms and conditions of the Creative Commons Attribution (CC BY) license (https:/ / creativecommons.org/licenses/by/ $4.0 /)$.
Head Department of Multidisciplinary Studies, The Max Stern Yezreel Valley College, Yezreel Valley 1930600, Israel; binan@yvc.ac.il

\begin{abstract}
The utopian notion that there is a time and place where perfect happiness exists is deeply rooted in Western thought and alienates people from life in the here and now. Happiness is perceived as the purpose of life. Moreover, happiness and suffering are presented as opposites that are contingent upon a person's actions. For thousands of years, happiness and the avoidance of suffering have been presented as the motives behind every action, and the conceptual basis for this still exists in contemporary discourse and culture. The roots of this perception can be found, inter alia, in the culture's religious texts. In this paper, we use the genealogical method to interrogate the religious and constitutive texts of Western culture and to examine the origins of the perception that happiness is the purpose of life and that it constitutes the opposite of suffering. The genealogical method enables us to deconstruct the causal relationship that lies at the core of this premise. Genealogy deals with the past, but its main purpose is the understanding and critique of contemporary reality; exposing the roots of our cultural past reduces the control of necessity over our lives.
\end{abstract}

Keywords: Western culture; Old Testament; happiness; Garden of Eden; genealogy; suffering

\section{Introduction}

Many in Western culture perceive happiness as the purpose of life and define it as the antithesis of suffering. In other words, the pursuit of greater happiness is complemented by a desire to minimize suffering. The utopian notion that there is a time and place where perfect happiness exists is deeply rooted in Western thought and alienates people from life in the here and now. The roots of this perception can be found, inter alia, in the culture's religious texts. In this paper, we use the genealogical method to interrogate religious and constitutive texts of Western culture in order to examine the cultural origins of the notion that happiness is the purpose of life and the opposite of suffering. We also attempt to deconstruct the causal relationship that underpins this premise. Genealogy concerns itself with the past, but its main purpose is the understanding and critique of contemporary reality; exposing the roots of our cultural past reduces the control of necessity in our lives. Genealogy allows for a reexamination of values and attitudes (Foucault 1977, p. 152).

Our adoption of the genealogical method as a critical practice leads us to the ideas of Nietzsche and Foucault-Nietzsche is considered the father of genealogy as a critical method and Foucault implemented and continued his work (Deleuze 2006, p. 2). As noted, the genealogical research corpus is taken from canonical religious texts within Western culture. Religion is a hallmark of culture; cultural thought and value systems are reflected in the religious doctrines of a given culture.

Western Christianity is a prominent feature of Western civilization, and it serves as a distinctive identity marker for this culture. Western culture and Christianity are largely based on the Old Testament, where happiness and suffering are represented as opposites contingent on a person's behavior. In both Christianity and Judaism, the Old Testament is considered a holy text - the absolute truth, a product of divine revelation. As such, it is still possible to recognize the imprint of myths and narratives originating in the biblical text as well as in other religious Christian sources in many Western cultural productions (Hacohen 2006, p. 23; Eliav-Feldon 2000, p. 30). Such myths are an inseparable part of 
religion, as some aspects of reality require mythical conceptualization, such as the domains of happiness and suffering. They are a way of imposing order on a world that does not make sense.

In these constitutive texts, happiness is perceived as the purpose of life, as an aspiration and goal, and as a reward. Happiness and suffering are presented as dichotomies that are contingent on an individual's behavior. For thousands of years, the pursuit of enjoyment and happiness and the avoidance of suffering and pain were presented as the motivations for every action, and the conceptual framework underlying this notion still informs our culture and discourse today.

\section{Discussion}

\subsection{The Myth of the Garden of Eden: Happiness without Suffering}

The Garden of Eden is a major origin myth, in both Judaism and Christianity, that is at the very foundation of Western culture. The Garden of Eden represents nostalgia for the past, abundance, and ultimate happiness, and expresses a life of harmony and a lack of suffering, although without any measure of self-awareness (Fromm 1975): "Now the Lord God had planted a garden in the east, in Eden; and there he put the man He had formed. The Lord God made all kinds of trees grow out of the ground-trees that were pleasing to the eye and good for food. In the middle of the garden were the tree of life and the tree of the knowledge of good and evil. A river watering the garden flowed from Eden; from there it was separated into four headwaters" (Gen 2:8-10 New International Version).

With the expulsion from Eden, suffering manifested as punishment, and man and woman became more aware, human, suffering, and longing for the past, and for Eden where ultimate happiness prevailed. Happiness has become nostalgia for times gone by or a yearning for the future. Happiness, as the story goes, belongs to the righteous, and suffering is presented as punishment for the sins committed by a person:

And I will put enmity between you and the woman, and between your offspring and hers ... To the woman He said, I will make your pains in childbearing very severe; with painful labor you will give birth to children. Your desire will be for your husband, and he will rule over you. To Adam he said, Because you listened to your wife and ate fruit from the tree about which I commanded you, 'You must not eat from it,' Cursed is the ground because of you; Through painful toil you will eat food from it all the days of your life... By the sweat of your brow you will eat your food until you return to the ground, since from it you were taken; for dust you are and to dust you will return (Gen 3:15-19 NIV).

In Western culture, the Garden of Eden represents not only the time and place of the expulsion but also a destination accessible to all righteous persons after their deaths. Happiness without suffering is inherent in the primal, pre-fall state, from which point, man's fate is encumbered by suffering, while happiness is promised to the righteous at the end of days.

Despite differences between biblical stories, a unified perception lies at the foundation of most biblical texts due to the direct and continuous linkage between sin and punishment. This direct linkage is portrayed throughout the Bible (Scholem 1992, p. 163):

However, if you do not obey the Lord your God and do not carefully follow all his commands and decrees I am giving you today, all these curses will come on you and overtake you: You will be cursed in the city and cursed in the country ... You will be cursed when you come in and cursed when you go out ... You will build a house, but you will not live in it. You will plant a vineyard, but you will not even begin to enjoy its fruit ... All these curses will come on you. They will pursue you and overtake you until you are destroyed, because you did not obey the Lord your God and observe the commands and decrees he gave you ... Just as it pleased the Lord to make you prosper and increase in number, so it will please him to ruin and destroy you (Deut 28:15-63 NIV). 
Israel's prophets guarantee happiness for the righteous and suffering for the sinner: "Tell the righteous it will be well with them, for they will enjoy the fruit of their deeds. Woe to the wicked! Disaster is upon them! They will be paid back for what their hands have done" (Isa 3:10-11 NIV). "But blessed is the one who trusts in the Lord, whose confidence is in him. They will be like a tree planted by the water ... It has no worries in a year of drought and never fails to bear fruit ... I the Lord search the heart and examine the mind, to reward each person according to their conduct, according to what their deeds deserve" (Jer 17:7-10 NIV).

However, as Job protested, suffering does not only appear in the context of punishment. Job does not accept the argument that suffering indicates sin; indeed, he is certain that he did not sin. Job is searching for the causal link to his suffering-based on the presumption that suffering manifests as punishment: "I say to God: Do not declare me guilty, but tell me what charges you have against me" (Job 10:2 NIV)—but does not find it. Job sees the events around him as arbitrary chaos inflicted by God; God causes multiple injuries without visible cause. God shows Job an ostensibly illogical and immoral world (Weiss 1983, p. 390). This approach does not link suffering to sin, but rather contends that suffering is God's way of testing the righteous (Abraham, Job) and not as punishment for their sins. Most portrayals of happiness in the Bible appear as a reward for the righteous, while descriptions of suffering appear in the context of punishment or trial-in terms of a causal connection. Only a few depictions communicate a perception of suffering and happiness as a natural part of life that is not related to the individual's behavior.

In Ecclesiastes, we are presented with a slightly different approach. Ecclesiastes suggests that we rejoice in our lives, be happy, take from the world what it has to offer, and not contemplate the nature of God and his motives. "When I applied my mind to know wisdom and to observe the labor that is done on earth-people getting no sleep day or night- then I saw all that God has done. No one can comprehend what goes on under the sun. Despite all their efforts to search it out, no one can discover its meaning. Even if the wise claim they know, they cannot really comprehend it" (Eccl 8:16-17 NIV).

\subsection{The End of Days and the Promise of Happiness According to Christianity}

The biblical, linear concept of time runs from creation until the end of days. It is on this continuum that history occurs (Dan 2000, p. 19). The Israelite Prophets dealt extensively with the end times and the happiness that was promised in the future to come as contingent on the behavior of the people and the community: "In the last days the mountain of the Lord's temple will be established as the highest of the mountains; it will be exalted above the hills, and peoples will stream to it" (Mic 4:1 NIV). "This is what the Lord says: 'Restrain your voice from weeping and your eyes from tears, for your work will be rewarded,' declares the Lord. 'They will return from the land of the enemy. So there is hope for your descendants,' declares the Lord. 'Your children will return to their own land'" (Jer. 31:16-17 NIV).

This belief in the end times penetrated Christianity mainly through the Book of Revelation, the Revelation of John the Divine, whose writing was influenced by the apocalyptical visions of Daniel, which served as an example for all subsequent visions: "He said: 'I am going to tell you what will happen later in the time of wrath, because the vision concerns the appointed time of the end'" (Dan 8:19 NIV). The Revelation of John contains a collection of visions composed at the end of the first century $\mathrm{CE}$ and which were attributed to John, the much-loved disciple of Jesus. The book is a call for Christians to persevere in their faith and to place hope in their ultimate victory over their enemies.

In Christianity, suffering exists in the corporeal world, and happiness in the kingdom of heaven (the Garden of Eden). The hope for future happiness is related to the belief in the end of days-"In the eschaton the light falls from above into our life ... The Christian message ... we already live here and now in anticipation of the eschaton" (Barth 1959, pp. 196-97). Christianity has taught us that in order to be happy in time T2 (the kingdom of heaven) we must suffer in time T1 (the corporeal world): "Blessed are the poor in 
spirit, for theirs is the kingdom of heaven. Blessed are those who mourn, for they will be comforted ... Blessed are those who are persecuted because of righteousness, for theirs is the kingdom of heaven ... Rejoice and be glad, because great is your reward in heaven" (Matt 5:3-12 NIV). Suffering is the means to happiness and glory: "For our light and momentary troubles are achieving for us an eternal glory that far outweighs them all. So we fix our eyes not on what is seen, but on what is unseen, since what is seen is temporary, but what is unseen is eternal" (2 Cor 4:17-18 NIV).

Suffering in Christianity is multifaceted: "We are hard pressed on every side, but not crushed; perplexed, but not in despair; persecuted, but not abandoned; struck down, but not destroyed" (2 Cor 4:8-9 NIV); suffering in Christianity prepares us to serve God: "If we are distressed, it is for your comfort and salvation" (2 Cor 1:6 NIV); “'We must go through many hardships to enter the kingdom of God,' they said" (Acts 14:22 NIV). In Christianity, genuine happiness is the yearning for a past time in the Garden of Eden or the longing for a future to come: "He will wipe every tear from their eyes. There will be no more death or mourning or crying or pain, for the old order of things has passed away" (Rev 21:4 NIV) - and as a result, happiness is also manifested in the anguish of longing and in the anticipation to regain lost happiness in life here and now.

\subsection{Suffering and Happiness: Twin Siblings}

In this paper, we attempt to deconstruct the linkage-which is at the foundation of Western culture-in terms of which happiness is the absence or reduction of suffering, or conversely, that suffering constitutes preparation for a happy, painless life. There is no wholeness to life without suffering, happiness is not the opposite of suffering, and they will always manifest together. There is no historical moment in which we can identify happiness without suffering. Suffering leads us to delve deeper within ourselves (Tillich 1951). Suffering and pleasure are not opposites. Pain is inherent in every pleasure. The escape from suffering can cause degeneration. The avoidance of suffering not only prevents the intensification of happiness but quite the opposite, it intensifies the suffering. Evasion from experiences, sincerity, the expression of feelings, and greater social involvement often stems from a fear of harm and suffering. Human beings are afraid of suffering, of the exploitation of their honesty, and thus, withdraw from society - in fact, escape reality, build a barrier between themselves and others, and often even increase their suffering by longing for an unattainable ideal reality of happiness instead of experiencing actual reality. The distance between our imagined perception of a happy, painless life and actual reality increases the pain.

Nietzsche calls happiness and suffering twin siblings (Nietzsche 1968, p. 221). They appear together, and both are products of life's necessities and activities. The fear of suffering is a fear of life itself. Happiness is life's imperative despite all that it involves-misfortunes, hardships, misgivings, and even calamities (Lurie 2006). A priori, the aspiration for greater happiness, which is accompanied by an aspiration for reduced suffering, has no chance of becoming a reality (Nietzsche 1968, p. 478). Facing danger indicates man's liberation from his need of God, of comfort and certainty. For Nietzsche, the ability to be happy embodies the ability to desire life in its entirety, and as Wittgenstein (1980, p. 78), claims, to be happy means to live in agreement with the world. The fear of suffering is the unwillingness to comply with life itself and the limitations enforced upon it is in fact the prevention of happiness related to meaning, agency, authenticity, creativity, love, community life, and a variety of actions whose experience involves happiness and suffering intertwined in life itself. Intense life events are experienced as a synergy of happiness and suffering.

The experience of love is a powerful testament to the fact that happiness and suffering can manifest themselves simultaneously and be as closely linked as conjoined twins. There are virtually countless films, novels, and poems that proclaim as much. Even the Old Testament contains descriptions of love as a potent mixture of happiness and suffering. The Song of Songs reflects an already widespread trope that views love as containing joy and life force, but also unexpected pain that one is powerless to avoid: "Place me like a 
seal over your heart, like a seal on your arm; for love is as strong as death, its jealousy unyielding as the grave. It burns like blazing fire, like a mighty flame. Many waters cannot quench love; rivers cannot sweep it away. If one were to give all the wealth of one's house for love, it would be utterly scorned" (Song 8:6-7, NIV).

A more comprehensive overview of the biblical text reveals that passionate and unbridled love toward another person necessarily entails great suffering alongside the great happiness it brings. The message, therefore, that the Old Testament wishes to impart is that only if God is made into the ultimate object of a human's passion, can love fulfill its promise: to be a positive and life-giving force of happiness.

\subsection{The Pursuit of Happiness}

Happiness and suffering are intertwined on life's journey; however, at the same time, the pursuit of happiness also leads to unnecessary suffering. The "race for success" in Western culture is often viewed as the pursuit of happiness. Once a goal has been achieved and we have succeeded in reaching our destination, we are happy for a week, a month, or even a single moment. However, this feeling is fleeting, and so we embark on the journey once more, in a hurry to succeed and achieve our next happiness. Scott Sandage (2005, p. 14) refers to this perception, in which the race for success is seen as the pursuit of happiness, as "the Holy Trinity" - life, ambition, and the pursuit of happiness.

Bertrand Russell (1952), in The Conquest of Happiness, discusses the causes of dissatisfaction with life in the Western world. Russell notes the pursuit of success as being among the key factors. It is this pursuit, Russell believes, that gives rise to a deficit of happiness. Russell describes the race for competitive success that society imposes on us as a "struggle for success" and as one of the causes for dissatisfaction and lack of happiness in life: "If you ask any man in America, or any man in business in England, what is it that most interferes with his enjoyment of existence, he will say: 'The struggle for life.' ... What people mean, therefore, by the struggle for life is really the struggle for success ... The trouble arises from the generally received philosophy of life, according to which life is a contest, a competition, in which respect is to be accorded to the victor" (pp. 37-38).

The assumption that external success results in happiness is also deeply rooted in Western culture and is found in biblical texts (Nir 2016, p. 117), in Greek philosophy, in Socrates, Aristotle, and others, and at various periods in Western culture. The culmination of this cultural myth is found in contemporary consumer capitalist culture, which greatly reinforces the belief that success and achievement lead to happiness.

The Book of Psalms opens with a clear expression of this concept: "Blessed is the one who does not walk in step with the wicked or stand in the way that sinners take or sit in the company of mockers, but whose delight is in the law of the Lord, and who meditates on his law day and night. That person is like a tree planted by streams of water, which yields its fruit in season and whose leaf does not wither-whatever they do prospers" (Pss 1:1-3 NIV).

Happiness is guaranteed for those who desire the teachings of God, and happiness is promised in the form of success and prosperity: "Blessed are all who fear the Lord, who walk in obedience to him. You will eat the fruit of your labor; blessings and prosperity will be yours. Your wife will be like a fruitful vine within your house; your children will be like olive shoots around your table" (Pss 128:1-3 NIV). Happiness is promised to the righteous as a reward for material success. According to the Hebrew concept of the Bible as interpreted by Sigmund Mowinckel, blessings of a human are nothing more than a life force expressed in happiness and success, while curses drain them of all goodness (Mowinckel, in Weiss 1983, p. 468).

At the same time, we can also find in the Bible an approach that attempts to deconstruct the link between success and happiness, such as here in Ecclesiastes: "What do people gain from all their labors at which they toil under the sun? Generations come and generations go, but the earth remains forever" (Eccl 1:3-4 NIV). At the conclusion of all his seeking and pondering on how to find a way to bring him to happiness, Ecclesiastes concludes that 
there is no path to be built on the goals of earthly life that will lead us to happiness or bring meaning to life. One cannot reach a life of happiness, and one should not seek happiness in external, worldly success (Cohen 2007, pp. 258-60). Ecclesiastes recognizes that worldly goods and pleasures cannot bring happiness and satisfaction to the soul. He explored the world, and when wisdom did not bring him happiness, he became addicted to success and pleasures, male and female slaves, silver and gold, property, and luxuries-as he put it, he did not deprive himself of anything that his eyes desired: "I denied myself nothing my eyes desired; I refused my heart no pleasure. My heart took delight in all my labor, and this was the reward for all my toil. Yet when I surveyed all that my hands had done and what I had toiled to achieve, everything was meaningless, a chasing after the wind; nothing was gained under the sun" (Eccl 2:10-11 NIV). Earthly pleasures and success only caused him disappointment, and he understood that it is not in human's power to change the world, since "All go to the same place; all come from dust, and to dust all return" (Eccl 3:20 NIV).

Catholic Christianity also severs the linkage between external, material success, and happiness, viewing competition, pride, and the pursuit of earthly successes as a sin, and preaching a life of modesty. The Sermon on the Mount stands in fundamental contrast to worldly success, and happiness is promised for those who do not seek this: "Blessed are the meek, for they will inherit the earth" (Matt 5:5 NIV) and those who have no wealth of "treasures on earth" (Matt 6:19 NIV).

As noted, the calls by religion to sever the linkage between happiness and worldly success is proof that this linkage exists within the culture. Furthermore, messages about the importance of happiness and success are also to be found within the Christian myth, which states that although success is important, it is to be rejected and reserved for the world to come: "Truly I tell you, at the renewal of all things, when the Son of Man sits on his glorious throne, you who have followed me will also sit on twelve thrones, judging the twelve tribes of Israel. And everyone who has left houses or brothers or sisters or father or mother or wife or children or fields for my sake will receive a hundred times as much and will inherit eternal life" (Matt 19:28-29, NIV).

In this context, it is interesting to note the words of Ludwig Feuerbach (1957, pp. 47-49), who argued that religion takes a winding, circuitous route to reach the same goal that people naturally rush directly toward. To believe in a future life is not to believe in a wholly unfamiliar life; the "beyond", after all, is merely the "here and now".

\section{Conclusions: Happiness, Success, and Suffering in Life's Journey}

At the core of Western culture, as we have seen, lies the assumption that the purpose of life is the realization of happiness. Many justify the Western race for success as being a formula for finding happiness. Therefore, success has become an object of aspiration for many who construct their self-image, self-worth, and, in many ways, also their identity, according to the accepted criteria of success, in particular, on a professional and an economic level (Strenger 2010, pp. 159-66). Theodor Adorno and Max Horkheimer see today's race for success as the sole measurement of self-existence: "Individuals define themselves now only as things ... successes or failures. Their criterion is selfpreservation, successful or unsuccessful adaptation to the objectivity of their function ..." (Horkheimer and Adorno 2002, pp. 21-22). The discourse of success as a guarantee of happiness takes place in the media, political rhetoric, education, and art (Nir 2016). As we have seen, the roots of this perception are found in the culture's constitutive religious texts, as is the perception that happiness is the absence of suffering.

At the same time, it is important to note the limitations of the genealogical method employed in this paper, which is based on the canonical religious texts underpinning Western culture. Western culture is rooted in and developed from additional sources, including the classical world (Deutsch 1981). In classical Greece, too, we find a linkage between success and happiness. Socrates linked happiness to human morality. Eudaimonia means happiness, success, or wellbeing. According to Socrates, everyday phenomena, such as money, respect, and health, which are generally considered to constitute the form of 
happiness that stems from external success, are not sufficient to confer true happiness and wellbeing. The contribution of these things to happiness is only evident if an individual is endowed with virtue. Socrates severs the linkage between external success and happiness, and between internal success and happiness. To be happy, a righteous person needs only his righteousness: "Most excellent man, are you who are a citizen of Athens, the greatest of cities and the most famous for wisdom and power, not ashamed to care for the acquisition of wealth and for reputation and honour, when you neither care nor take thought for wisdom and truth and the perfection of your soul? ... I tell you that virtue does not come from money, but from virtue comes money" (Plato [1914] 2005, pp. 109-11). Socrates, too, emphasizes the close link between morality and happiness: "Then the happiest is the person who has no badness in his soul" (Plato 2004, p. 59).

Socratic philosophy recommends that we find inner happiness. Nietzsche, too, recommends introspection; however, as noted, he makes the connection between the discovery of inner happiness and suffering as being a necessary pair on life's journey. A life full of happiness and significance, according to Nietzsche, is related to the term "self-overcoming" and there is no self-overcoming without suffering. In the process of overcoming, one experiences the immense joy of discovery, however, it is entwined with suffering: "But the worst enemy whom you can encounter will always be yourself; you ambush yourself in caves and woods ... You must want to burn yourself up in your own flame: how could you become new if you did not first become ashes!" (Nietzsche 2006, p. 47).

The hero who overcomes themselves is one who enables themselves to face their emotions and to feel their pain and suffering. Individuals who do not enable this will be inaccessible, rigid, and superficial and will not succeed in embarking on life's journey. Suffering motivates the individual to embark on a journey of growth and development. To prevail over suffering and contain it, one must be tolerant (Netzer 2011).

Existential suffering stems from our experiencing ourselves as captives in time (Sarte 1958). Suffering is caused not only by mental traits and difficult, painful, and harmful life events but also by the manner in which the individual copes with them. Awareness of the individual's part in creating his own suffering is the foundation for change (Netzer 2011). One who finds meaning in suffering and renders it a lever for internal growth develops the mental qualities of a hero who takes steps toward a journey to the self-a journey that also entails great happiness. Insufferable experiences often incorporate many happy moments, as Viktor Frankl accurately articulated in his book Man's Search for Meaning. Frankl describes the unbearable suffering he experienced in Auschwitz and his attempt to find meaning, hope, and even happiness within "hell": "I understood how a man who has nothing left in this world still may know bliss, be it only for a brief moment, in the contemplation of his beloved" (Frankl 1992, p. 49).

As noted, while happiness and suffering are intertwined in life's journey, the unnecessary pursuit of happiness leads to unnecessary suffering. The Roman philosopher, Seneca, argues that the pursuit of happiness causes the individual's inability to distinguish between happiness and pleasure. This misconception not only distances the individual from happiness but also causes him or her to suffer: "Even those people who declare the highest good to be in the belly, see what a dishonorable position they have assigned to it ... it is owing to pleasure itself that they are unhappy ... Virtue is a lofty quality ... pleasure is low, slavish, weakly, perishable ... [it] fades away as soon as its first impulse is over" (Seneca 1900).

While we have examined the roots of culture in religious texts, it is important to focus future research on mass-marketed capitalist structures of happiness. Contemporary capitalist culture presents structures of happiness for marriage, parenthood, material success, and careers, and markets certain formulae for a "correct" and happy life, free of suffering. These formulae for a "happy" life invite comparison between individuals' lives and these structures-and such comparisons increase suffering and frustration. In contrast, the philosopher Søren Kierkegaard proposes an existence unmotivated by comparison to others; The restless culture of comparison tempts people to imagine themselves in the 
place of others, or to imagine the other in his or her own place. However, the other is never in my place, nor am I in the place of the other. Comparison only distances people from themselves, from their very existence. Those who experience their existence from inside, from the inside out, hear the invitation to rejoice in their lot. On the other hand, those who experience their existence from the outside in, that is, those who know themselves only through comparison to others, refuse to rejoice and to be happy with their lot. This comparative worry comes at the cost of losing one's joy in life, suffering jealousy, a feeling of victimhood and self-pity, as well as losing the freedom to live simply (Kierkegaard 1980). Focusing on the ideals of happiness, and on the structures of happiness that are currently mass-marketed to us, alienates us from ourselves and increases our suffering. The search for inner, personal, authentic meaning, which cannot be subject to comparison with others, is an answer to the suffering engendered by the pursuit of happiness.

Funding: This research received no external funding.

Institutional Review Board Statement: Not applicable.

Informed Consent Statement: Not applicable.

Data Availability Statement: Not applicable.

Conflicts of Interest: The author declares no conflict of interest.

\section{References}

Barth, Karl. 1959. Dogmatics in Outline. Translated by George Thomas Thompson. New York: Harper \& Row Publishers.

Cohen, Adir. 2007. Marpe Philosophi (Philosophical Therapy). Haifa: Amatzia.

Dan, Yosef. 2000. Apokalipsah az Veachshav (The Apocalypse then and Now). Herzliya: Yedioth Aharonoth and Seferei Chesed.

Deleuze, Gilles. 2006. Nietzsche and Philosophy. Translated by Hugh Tomlinson. New York: Columbia University Press.

Deutsch, Karl. 1981. On Nationalism, World Regions and the Nature of the West. In Mobilization, Center-Periphery Structures and Nation-Building. Edited by Per Torsvik. Bergen: Universitetsforlaget, pp. 51-93.

Eliav-Feldon, Miriam. 2000. Mahapehat ha-Defus (The Print Revolution). Tel Aviv: Ministry of Defense Press.

Feuerbach, Ludwig. 1957. The Essence of Christianity. New York: Frederick Ungar Publishing.

Foucault, Michel. 1977. Nietzsche, Genealogy, History. In Language, Counter-Memory, Practice. Edited by Donald F. Bouchard. Ithaca: Cornell University Press.

Frankl, Viktor. 1992. Man's Search for Meaning: An Introduction to Logo-Therapy. Translated by Ilse Lasche. New York: Washington Square. Fromm, Erich. 1975. You Shall Be as Gods. New York: Holt, Rinehart \& Winston.

Hacohen, Ran. 2006. Mehadshei ha-berit ha-yeshenah: Hitmodedut hokhmat Yisrael ba-Germania im bikoret ha-Mikra ba-meah ha-tisha-asar (Reclaiming the Hebrew Bible: German-Jewish Reception of Biblical Criticism). Bnei-Brak: HaKibbutz Hameuhad.

Horkheimer, Max, and W. Theodor Adorno. 2002. Dialectic of Enlightenment: Philosophical Fragments. Edited by Gunzelin Schmid Noer. Translated by Edmund Jephcott. Stanford: Stanford University Press.

Kierkegaard, Søren. 1980. The Lily in the Field and the Bird of the Air. In The Essential Kierkegaard. Edited by Howard V. Hong and Edna H. Hong. Princeton: Princeton University Press.

Lurie, Yuval. 2006. Tracking the Meaning of Life: A Philosophical Journey. Columbia: University of Missouri Press.

Netzer, Ruth. 2011. Masa HaGibor: Tahalikh hitavut ha-nefesh ba-mitus, b'maagal ha-haim u be-terapia (The Hero's Journey: The Becoming of the Spirit in Myth, Life Circle and Therapy). Ben Shemen: Modan.

Nietzsche, Friedrich. 1968. The Will to Power. Translated by Walter Kauffman, and Reginald John Holingdale. New York: Vintage.

Nietzsche, Friedrich. 2006. Thus Spoke Zarathustra. Translated by Adrian Del Caro. Cambridge: Cambridge University Press.

Nir, Bina. 2016. Kishalon HaHatzlacha (The Failure of Success). Tel Aviv: Resling.

Plato. 2005. Euthyphro, Apology, Crito, Phaedo, Phaedrus. Translated by Harold North Fowler. Cambridge: Harvard University Press. First published 1914.

Plato. 2004. Gorgias. Translated by Walter Hamilton. London: Penguin Classics.

Russell, Bertrand. 1952. The Conquest of Happiness. New York: New American Library.

Sandage, Scott A. 2005. Born Losers-A History of Failure in America. Cambridge: Harvard University Press.

Sarte, Jean Paul. 1958. L'existentialisme est un Humanisme (Existentialism Is a Humanism). Paris: Editions Nagel.

Scholem, Gershom. 1992. "Al het va-onesh" (On sin and punishment). In Od Davar (Explications and Implications: Writings on Jewish Heritage and Renaissance). Tel Aviv: Am Oved.

Seneca, Annaeus. 1900. On the Happy Life. Translated by Aubrey Stewart. London: George Bell \& Sons.

Strenger, Carlo. 2010. Ani, proiekt mitug_individualiut vemashmaut baidan haglobali (The Self, A Branding Project-Individualism and Meaning in the Global Age). Tel Aviv: Kineret Zmora Bitan.

Tillich, Paul. 1951. Systematic Theology. Chicago: University of Chicago Press. 
Weiss, Meir. 1983. The Story of Job's Beginning: Job 1-2: A Literary Analysis. Jerusalem: Hebrew University Press.

Wittgenstein, Ludwig. 1980. Culture and Value (1977). Edited by Georg Henrik von Wright. Translated by Peter Winch. Oxford: Basil Blackwell. 